\title{
Pemanfaatan Internet Sebagai Sumber Belajar
}

\section{Rimba Sastra Sasmita}

\author{
Pendidikan Guru Sekolah Dasar \\ Fakultas Keguruan dan Ilmu Pendidikan \\ Universitas Kristen Satya Wacana \\ Email: sastrasasmitarimba@gmail.com
}

\begin{abstract}
Abstrak
Penelitian ini berjudul pemanfaatan internet sebagai sumber belajar. Penelitian ini bertujuan untuk mengetahui manfaat internet sebagai sumber belajar. Penelitian ini merupakan penelitian dengan studi kepustakaan menggunakan metode deskriptif. sumber data dari penelitian ini berupa jurnal-jurnal terkait tentang pemanfaatan internet sebagai sumber belajar. Teknik penggumpulan data menggunakan teknik menyimak dan mencatat. Teknik validasi data menggunakan Triangulasi data. Analisis data menunjukkan bahwa internet memiliki manfaat sebagai sumber belajar yang dapat diterapkan dalam pembelajaran atau dalam kegiatan belajar mengajar. Bentuk pemanfaatan internet sebagai sumber belajar antara lain mendukung kegiatan pembelajaran, internet sebagai sumber informasi. Hasil penelitian menunjukkan bahwa semua orang telah menggenal dan menggunakan internet.
\end{abstract}

Kata kunci: Internet, Sumber Belajar

\section{PENDAHULUAN}

Sebelum adanya internet, masalah utama yang di hadapi oleh pendidikan adalah akses kepada sumber informasi. Penggunaan internet sebagai media pembelajaran dapat diangap sebagai suatu hal yang sudah jamak digunakan dikalangan pelajar. Dengan adanya internet sebagai sumber belajar memudahkan kita untuk mengakses berbagai sumber informasi yang tersedia, karena internet dapat membantu kita meningkatkan taraf hidup melalui pendidikan. Internet juga dapat mengakses berbagai referensi, baik yang berupa hasil penelitian, maupun artikel hasil kajian dalam berbagai bidang. Informasi yang tersedia dan dapat diakses melalui internet terjadi di seluruh dunia (global world). Sebenarnya internet bisa menjadi sumber belajar alternatif yang cukup efektif dan efisien, namun selama ini yang umum dikenal sebagai sumber belajar adalah buku dan pendidik. Untuk itu sekolah-sekolah bisa menjadikan internet sebagai sarana untuk belajar selain buku. Semakin pesat perkembangan penggunaan internet juga turut meningkatkan nilai manfaat dari internet itu sendiri. Pesatnya perkembangan internet baik di negara maju maupun di negara yang sedang berkembang salah satu teknologi informasi yang berkembang adalah internet. 
Pemanfaatan internet dalam penelitian tersebut merupakan pemanfaatan internet secara umum yaitu baik untuk mencari informasi untuk menunjang kegiatan belajarnya maupun untuk hiburan, bermain dan sebagainya. Selain itu, hasil penelitian yang dilakukan Pibriana dan Ricoida (2007); Arlia dan Sumiati (2015); Nugrahini dan Margunani (2015) menyimpulkan bahwa penggunaan internet berpengaruh signifikan terhadap motivasi dan minat belajar siswa, artinya penggunaan internet oleh siswa dapat meningkatkan motivasinya untuk melaksanakan kegiatan belajar.

Menurut Hamalik (2003) menyatakan bahwa berhasil atau tidaknya seseorang dalam belajar diantaranya disebabkan oleh faktor yang berasal dari luar seperti kesediaan sumber belajar, maupun yang berasal dari dalam diri siswa itu sendiri, seperti motivasi dan minat mempelajari sesuatu.

\section{METODOLOGI PENELITIAN}

Jenis Penelitian. Metode yang digunakan dalam penelitian ini adalah metode penelitian kualitatif. Metode penelitian kualitatif adalah metode dalam bentuk deskripsi yang hasilnya berupa kata-kata atau gambar.

Sumber data dalam penelitian ini adalah dari jurnal-jurnal yang berkaitan dengan judul penelitian.

Teknik Penggumpulan Data. Teknik Penggumpulan Data dalam penelitian ini menggunakan teknik mencatat dan menyimak. Teknik validasi menggunakan Triangulasi data. Triangulasi data mengarahkan peneliti agar di dalam menggumpulkan data, wajib menggunakan beragam sumber data yang berbeda-beda yang tersedia.

Teknik Analisis Data. Teknik analisis data menggunakan reduksi data, display data, dan penarikan kesimpulan.

\section{HASIL PENELITIAN DAN PEMBAHASAN}

Pada dunia pendidikan, internet akan sanggat baik bila digunakan sebagai salah satu sumber belajar, seperti yang dikatakan oleh Arif Sudirman(1989) yang dikuip oleh Ahmad Rohani dan Abu Rahmadi (1991) bahwa segala sesuatu diluar peserta didik yang memungkinkan terjadinya proses belajar disebut sumber belajar yaitu teknologi internet yang berfungsi untuk memberikan kemudahan dan keleluasaan dalam menggali ilmu pengetahuan. Dengan menggunakan internet peserta didik semakin banyak mendapatkan informasi dan mendapatkan pengetahuan maka, prestasi akan semakin meningkat.

Nasution (2006) mengungkapkan bahwa internet memberi keuntungan dalam semua bidang bisnis, akademis (pendidikan), pemerintah, organisasi dan lain sebagainya. Beberapa manfaat yang diperoleh dari internet anatara lain: komunikasi interaktif, akses ke pakar, akses ke perpustakaan, membatu penelitian dan pengembangan ilmu pengetahuan, pertukaran data, dan kolaborasi.

Dalam buku karangan Anonim (2005, Sekilas Perkembangan Internet di Indonesia), disebutkan beberapa manfaat internet bagi pendidikan di Indonesia, yaitu: akses ke perpustakaan, akses ke pakar, perkuliahan online, layanan informasi akademik, menyediakan fasilitas mesin pencari data, menyediakan fasilitas diskusi, dan fasilitas kerjasama.

Internet juga dapat digunakan sebagai sumber alternatif selain buku untuk memudahkan mencari informasi sebanyak mungkin, internet adalah sebagai sumber belajar yang dimanfaatkan oleh guru dalam mengembangkan profesinya, karena dengan internet guru dapat meningkatakan pengetahuan, berbagi informasi diantar rekan sejawat, bekerjasama dengan pengajar di luar negri, kesempatan mampublikasikan informasi secara langsung, dan mengatur kominikasi 
secara teratur. Pemanfaatan internet sebagai sumber pembelajaran mengkondisikan peserta didik untuk belajar secara mandiri. Siswa dapat mengakses secara online sumber belajar seperti mencari informasi pembelajaran melalui google dan yahoo, mencari data yang berkaitan dengan pelajaran dan perpustakaan online (Munadi, 2013).

Menurut Adri (2007) pemanfaatan jaringan internet sebagai sumber dan sarana pembelajaran, dapat di implementasikan sebagai berikut:

1. Browsing, merupakan istilah umum yang digunakan bila hendak menjelajahi dunia maya/web.

2. Ressourcing adalah menjaikan internet sebagai sumber pengajaran.

3. Searching merupakan proses pencarian sumber pembelajaran guna melengkapi materi yang akan disampaikan kepada peserta didik.

\section{Consulting dan Communicating}

Dengan adanya internet guru dan siswa menjadi sanggat terbantu ketika mencari informasi yang berhubungan dengan pembelajaran karena menurut Association for Educational Communications and Technology sumber belajar adalah segala sesuatu atau daya yang dapat dimanfaatkan oleh guru, baik secara terpisah maupun dalam bentuk gabungan, untuk kepentingan belajar mengajar, dengan tujuan meningkatkan efektifitas dan efisiensi tujuan pembelajaran. Sumber pembelajaran dapat di kelompokkan menjadi dua bagian yaitu:

1. Sumber pembelajaran yang sengaja direncanakan (learning resources by design), yakni semua sumber yang secara khusus telah dikembangkan sebagai komponen sistem intruksional untuk memberikan fasilitas belajar yang terarah dan bersifat formal; dan

2. Sumber belajar yang karena dimanfaatkan (learning resources by utilization), yakni sumber belajar yang tidak secara khusus di desain untuk keperluan pembelajaran namun dapat ditemukan, diaplikasikan dan dimanfaatkan untuk keperluan belajar salah satunya adalah media masa.

Beberapa pengertian sumber belajar menurut Hamalik dalam Priyadi (1998:24) adalah sebagai berikut:

a. Sumber belajar adalah segala sesuatu yang dapat digunakan sebagai bahan/acuan dalam menambah pengetahuan dan kemampuan peserta didik.

b. Sumber belajar adalah suatu sistem atau perangkat materi yang sengaja diciptakan atau disiapkan dengan maksud memudahkan peserta didik (siswa) belajar.

c. Sumber belajar dapat berupa perangkat keras yang bisa disebut alat bantu ajar dan perangkat lunak disebut bahan ajar.

Di dalam dunia pendidikan internet mempunyai arti yang sanggat luas yaitu dapat mengubah cara pendidikan tradisional menuju arah yang lebih modern dan internet yang sudah diajarkan oleh guru kepada peserta didik dengan baik juga merupakan sebagian dari cara membantu mengurangi anak yang buta akan internet. Keaktifan peserta didik dituntut untuk memahami sesuatu karena keterbatasan jarak dan sumber informasi telah teratasi dengan adanya internet tersebut. Menurut Hardjito (2005) Peran internet bagi pelajar untuk mengembangkan daya atau kemampuan berfikir kritisnya yaitu sebagai berikut.

1. Akses ke sumber informasi

Sebelum adanya internet, masalah utama yang dihadapi oleh dunia pendidikan khususnya pada peserta didik adalah akses ke sumber informasi. Perpustakaan konvensional merupakan sumber informasi yang tidak murah. Buku-buku harus dibeli dengan harga mahal. Pengelolaan yang baik terhadap buku juga tidak mudah. Akibatnya, 
banyak tempat di berbagai lokasi di dunia yang tidak memiliki perpustakaan yang lengkap. Adanya internet memungkinkan mengakses kepada sumber informasi yang mulai tersedia banyak. Di Indonesia, masalah kelangkaan sumber informasi konvensional (perpustakaan) lebih berat dibandingkan dengan di tempat lain. Adanya internet merupakan satu solusi untuk mengatasi masalah tersebut dan membantu peserta didik untuk mendapatkan informasi sebanyakbanyaknya untuk keperluan pengembangan bagi diri sendiri.

2. Akses ke pakar

Internet boleh dikatakan telah menghilang batas antara ruang dan waktu sehingga memungkinkan seorang peserta didik di suatu tempat dapat berkomunikasi dengan seorang pakar atau ahli yang mungkin bisa membantu dalam pengembangan daya atau kemampuan berpikir kritis.

3. Media kerjasama

Kolaborasi atau kerjasama antara pihakpihak yang terlibat dalam bidang pendidikan dapat terjalin dengan mudah dan lebih efisien. Seperti yang dapat dilakukan pleh mahasiswa di satu tempat dengan mahasiswa lain di tempat lainnya dengan cara berdiskusi atau saling bertanya dan bertukar informasi mengenai suatu hal. Dengan seperti ini mereka akan mengalami perkembangan dalam kemampuan dan wawasan yang dapat membantu proses berpikir kritis.

Menurut Darmawan (2014: 34) internet adalah sebuah media belajar yang dapat dimanfaatkan sebagai sumber belajar dalam aktivitas belajar, sehingga siswa dapat memperoleh informasi atau bahan belajar dengan cepat. Internet dengan berbagai fasilitas-fasilitas yang dimiliki dapat menjadi komponen penting dalam kegiatan belajar, khususnya sebagai sumber belajar. Berbagai informasi yang dapat digali melalui internet, sehingga dapat mempermudah proses belajar. Hal tersebut sejalan dengan pendapat Setiyani (2010: 119) yang mengatakan bahwa internet memiliki banyak manfaat bagi akademisi, khususnya mahasiswa karena internet dan memudahan dalam pencarian jurnal, referensi, materi kuliah, hingga hasil penelitian yang dipublikasikan dalam jumlah yang banyak dan cepat, sehingga dapat menghemat tenaga dan biaya dalam mencari sumber belajarnya. Menurut Rahardjo, (2001) manfaat internet bagi pendidikan, antara lain untuk akses ke sumber informasi, akses ke pakar, maupun media kerjasama.

\section{SIMPULAN}

Berdasarkan hasil penelitian tentang penggunaan internet sebagai sumber belajar di dalam dunia pendidikan internet mempunyai arti yang sanggat luas yaitu dapat mengubah cara pendidikan tradisional menuju arah yang lebih modern dan internet yang sudah diajarkan oleh guru kepada peserta didik dengan baik juga merupakan sebagian dari cara membantu mengurangi anak yang buta akan internet. Internet memiliki manfaat seperti memudahkan kita untuk mengakses berbagai sumber informasi yang tersedia, karena internet dapat membantu kita meningkatkan taraf hidup melalui pendidikan. Internet juga dapat mengakses berbagai referensi, baik yang berupa hasil penelitian, maupun artikel hasil kajian dalam berbagai bidang. Dengan menggunakan internet peserta didik semakin banyak mendapatkan informasi dan mendapatkan pengetahuan maka, prestasi akan semakin meningkat.

\section{SARAN}

Berdasarkan hasil penelitian bahwa internet sebagai sumber belajar sebaiknya lebih di manfaatkan dengan baik dalam pembelajaran agar internet bisa menjadi sumber belajar alternatif yang cukup efektif dan efisien. 


\section{DAFTAR PUSTAKA}

Adri, Muhammad. 2007. Pemanfaatan Internet sebagai Sumber Pembelajaran. Makalah dalam rangka Semiloka Pengembangan Model Pembelajaran Berbasis Teknologi Informasi FT Padang, 22-23 Agustus 2007. (http://muhammadadri .wordpress.com.) diambil tanggal 8 November 2009.

Anonim. (2005). Sekilas Perkembangan Internet di Indonesia. (www.sejarahinternet.com). Diambil tanggal 09 Juli 2012.

Arlia, S dan Sumiati A. (2015). Hubungan Antara Pemanfaatan Media Internet Sebagai Sumber Belajar Terhadap Motivasi Belajar Siswa Kelas X Akuntansi SMK Negeri 46 Jakarta. Jurnal EconoSains, Volume XIII, Nomor 1. Diperoleh pada 17 Januari 2018.

Darmawan, D. (2014). Pengembangan Elearning Teori dan Desain. Bandung: PT Remaja Rosdakarya

Hamalik. 2013. Kurikulum dan Pembelajaran. Jakarta: Bumi Aksara.

Hardjito. 2005. Internet untuk Pembelajaran. (http://www.pustekkom.go.id).

Diakses 3 Maret 2011

Munadi, Yudhi. 2013. Media Pembelajaran(Sebuah Pendekatan Baru). Jakarta: Gp Press Group.

Nasution, Laila Hadri. 2006. Pemanfaatan Internet Guna Mendukung Kegiatan Perkuliahan Mahasiswa Program Pascasarjana UNIMED. http://library.usu.ac.id/downloads/fs/ 06005176.pdf. diambil tanggal 8 November 2009

Nugrahini, R.W dan Margunani. (2015). The Effect of Family Environment and Internet Usage on Learning Motivation. Jurnal Dinamika Pendidikan, 10 (2) 166 - 175.

Diperoleh pada 23 Februari 2018.
Pibriana, D dan Ricoida, D.I. (2017). Analisis Pengaruh Penggunaan Internet Terhadap Minat Belajar Mahasiswa (Studi Kasus: Perguruan Tinggi di Kota Palembang). Jatisi, Vol. 3 No.2. Diperoleh pada 28 Desember 2017.

Rahardjo, Budi, 2001. Internet Untuk Pendidikan.

Setiyani, R. (2010). Pemanfaatan Internet Sebagai Sumber Belajar. Jurnal Pendidikan Ekonomi Dinamika Pendidikan, Vol. V, No. 2 Hal. 117 133. Diperoleh pada 12 Februari 2018. 